\title{
普天間飛行場基地跡地計画における緑地計画に関する提案型研究
} 一広域の地下水需給構造の解明による流域別緑地配分の必要性を唱えたアクションリサーチー

\section{A PROPOSAL-BASED RESEARCH ABOUT THE OPEN SPACE PLANNING OF THE REUSE FUNDAMENTAL PLAN OF THE MARINE CORPS AIR STATION FUTENMA IN OKINAWA PREF., JAPAN}

- An action research for discussing the necessity of the watershed-based open space plan under the consideration of the water supply demand structure in Ginowan Area -

\author{
栄野川 優也*, 小 野 尋子** \\ Yuya ENOKAWA and Hiroko ONO
}

\begin{abstract}
This study aimed to clarify two study objectives. The 1st goal is to calculate exact a water balance model about approx. 1617ha of the 5 watershed areas, A,B,C,D and E, in Ginowan City where the Futenma Air Station is located in. The 2nd goal is to review the open space plan in Futenma reuse plan to fit water demands in these areas by using our water balance model. We researched water amount of springs that locate in 5 watershed areas by by flow speed measurement and positive displacement flowmeter. We calculated each land use area by GIS and interviewed the demands to establish water balance model. Then we simulated the effect of water supply of the contemporary Reuse plan. This study's consequences and contribution are three points. 1) The water balance model of this area is established. 2) The underground water and spring water demand of this area are calculated. 3) Through continuing discussion with parties, our proposal-based study is accepted in the public reuse plan of Futenma.
\end{abstract}

\section{Keywords : M arine Corps Air Station F utenma, Reuse Plan, Catchment Water Budget, O pen Space Plan} 普天間飛行場，跡地利用計画，流域水収支，緑地計画

\section{1. 研究の背景と目的、方法}

宜野湾市米軍普天間飛行場 (以下、普天間) は、平成 8 年に、日米特別 行動委員会 ( S A C O ) において全面返還が合意された。沖縄県及び宜 野湾市では、平成 18 年 2 月の『普天間飛行場跡地利用基本方針』を皮 切りに、上位計画の改訂や地元意向を踏まえ、順次検討・見直しをして きている。順次検討・見直しを経て、平成 25 年 3 月に「全体計画の中間

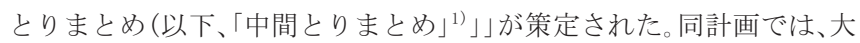
規模緑地 (100ha) の創出と基地内に残存する自然環境・歴史文化等の 資源の保全をベースとした土地利用配置の指針が定められ、その方針 は地主、住民、行政間で一定の理解と合意が得られつつある。

「中間とりまとめ」では、緑地の創出と現在の地下水系の保全の方針 がまとめられた。しかし、平成 27 年 8 月時点まで大規模緑地面積 $100 \mathrm{ha}$ の量的根拠及び緑地と地下水涵養の関係についての調查検討は、行政 でも民間でもなされていなかった。中間とりまとめ」の中では地下水 の保全の必要性については位置づけられているものの、同方針策定後 から平成 27 年 8 月の間に、(1)地下水涵養の観点ではどの程度の緑地の 保全が必要か(必要緑地の量的検討)、(2)地下水の現在および将来的な
需要をどの程度見込んで地下水を涵養しなければならないのか(地下 水の現在および将来需要面での検討)、(3)複数ある流域の中でどの流 域で地下水確保が重要なのか(緑地配置の流域別検討)等についての 検討がなされていなかった。それにも関わらず、平成 27 年度には行政 の計画段階が「保全の検討」から、基地跡地内への導入機能の検討とい う「利活用の検討」段階へと移りつつあった。しかし、(1)〜(3)の観点は、 土地利用基本構想の中でも、広大な面積を占める大規模緑地の「緑地 量」及び「緑地の配置」の目安として、重要な指標であり、土地利用計画 で導入機能の検討に入る前に整理すべき事項であった事から、早急な 調查と成果の計画への反映が求められた。そこで、大学から行政に調 查の実施を打診したが、共同調査の体制が整わなかったため、研究室 が先行して調查を実施し、緩やかな勉強会の中で行政や地元に結果を 還元・共有し提案するという体制で進めた。

本研究では、2 段階で研究を遂行した。まず、現在の普天間飛行場周 辺の湧水量について調査し (3 章)、現状の流域別土地利用状況から水 収支モデルを作成（4 章）したのちに、3 章の湧水量の観測值と 4 章の 水収支モデルから導出される湧水量の理論值の整合性を鑑みながら
* 琉球大学工学部環境建設工学科

** 琉球大学工学部 准教授・博士 (社会工学)
Under Graduate Student, Architecture Course, Faculty of Civil Engineering, University of Ryukyus Assoc. Prof., Faculty of Civil Engineering, University of Ryukyus, Ph.D. 
現在の宜野湾市の各流域の水収支を説明するモデルを作成すること を第一段階の目的とする (5 章)。次に、家庭及び産業での現在の地下水 利用の実態、及び将来需要を調査し (6 章)、「中間とりまとめ」の土地利 用計画で開発した場合の地下水への影響を水収支モデルにより算定 し、6 章の需要量と水収支の推計結果より、普天間内の緑地量と流域別 緑地配置の検討を行う (7 章)。最終的に、県及び市、地主会に対して水 収支や緑地保全の観点から跡地利用計画を考えていくことの必要性 を提案・協議 (8 章)することを目的とする。

研究の方法は、3 章では、宜野湾市の過去の調査と独自調査を統計的 に処理し、年間湧水量について推計を行った。4 章はGIS を用いて流域 別に現況の土地利用用途別の面積を計測し、土地利用用途別流出係数 に各面積を乗じて、流域別の雨水地下浸透量を推計した。6 章は各団体 や個人に地下水・湧水の利用用途、利用量に関するヒアリングを行っ た。7 章は 4 章で作成した水収支モデルを用いて、「中間とりまとめ」の 土地利用計画による地下水一の影響を算出し、緑地の適正配置により、 流域別に異なる地下水需要への対応が可能になる事を試算した。8 章 では、本研究のアクションリサーチの経緯と行政や地権者をはじめと する関係者とのやり取りをまとめた。

\section{2. 宜野湾市の地形・地質、表流水及び地下水流域の分類}

宜野湾市の地形は北西側に下る海岸段丘が形成されており、地表分 水嶺となる最も海抜の高い長田付近から 2 つの段丘を形成して海に至 る(図 1 の地形と地層)。普天間飛行場は第二の段丘上に立地し、地質 は全て琉球石灰岩土培となっている ${ }^{2)}$ 。GIS で計測すると基地跡地内 の緑地比率は約 70\% と周辺の既成市街地と比較して非常に高い。琉球

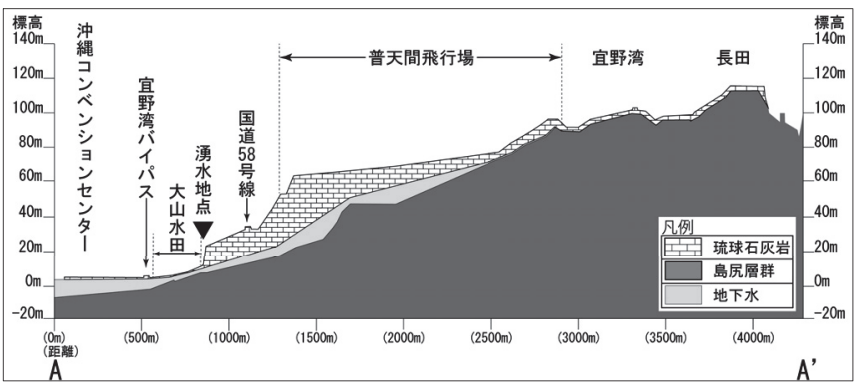

図 1 宜野湾市の地形・地層断面と地下水の形成状況

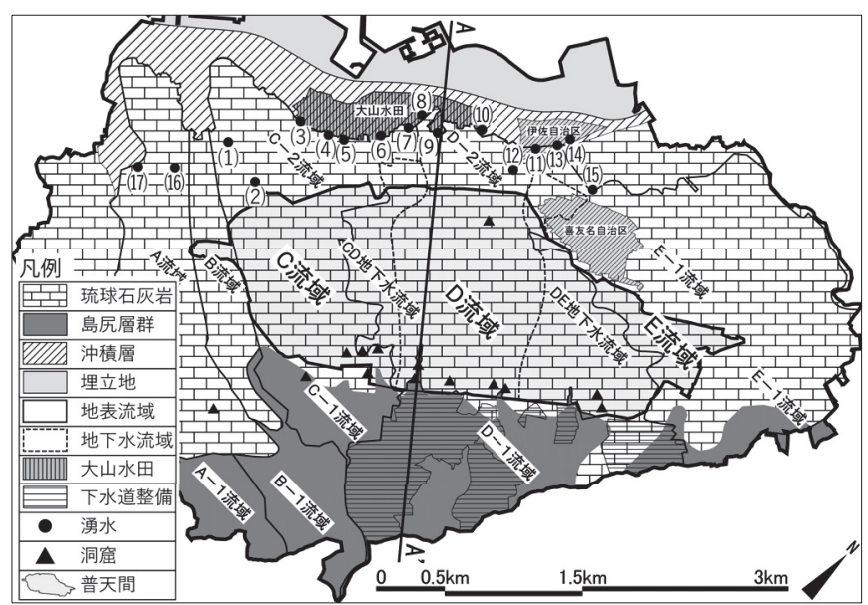

図 2 宜野湾市の地質と表流水及び地下水流域分類図
石灰岩はその特性により表流水を形成しないため、流域上部から流れ てきた雨水は普天間飛行場部分で、地下に浸透し、不透水層まで浸水 した後に地下で水脈や水盆を形成し、北西部の海岸低地 (大山水田周 辺) から湧水として再び地上に表出する(図 1 の地下水)。宜野湾市の 表流水及び地下水流域は、分水嶺、不透水基盤の等高線及び市内に整 備された下水道(雨水排水)により大きく分けて 5 つに区分され $\mathrm{A} \sim \mathrm{E}$ 流域 (流域面積:約 1620 万 $\mathrm{m}^{2}$ ) と表される。このうち普天間飛行場に大 きく関わる流域は $\mathrm{C} \sim \mathrm{E}$ (流域面積:約 480 万 $\mathrm{m}^{2}$ ) 流域である (図 2 )。

\section{3. 涌水量の実測データを元にした母涌水量の区間推定}

\section{3-1. 既存の湧水量調査データ $\left(N_{1}\right) 、$ 独自の追加調査 $\left(N_{2}\right)$}

湧水に関する既存調查は、平成 16 年度、 18 年度、 22 年度、 24 年度の宜 野湾市自然環境調查 ${ }^{344) 556)}$ において行われた流量調查結果 (表 $1 \mathrm{~N}_{1}$ )が ある。しかし、既存の調査は、(1)観測日が月に 1 回程度であることから 降水量を考慮できないという久陷注1)、(2)調査年度により計測地点や 方法が異なるというデータの不備があるため、平成 27 年 9 月 14 日か ら平成 28 年 1 月 30 日に計 62 回の流量調査を独自に実施した $\left(\right.$ 表 $\left.1 \mathrm{~N}_{2}\right)$ 。 特に(1)に関しては、現地調查でいくつかの湧水口では雨天後の湧水の 増加が確認されていたことから、湧水量を推定する上で考慮が不可欠 であった。独自調查の対象は現在も家庭用及び産業用として取水が行 われている湧水地点 ( (3)メンダカリヒーガー、(6)アラナキガー、(7) ヤマチヂャガー、(8) ウーシヌハナガー、(9) ヒャーカーガー、(11)ふん しん川、(14) ウフガー(図 2、表 2) )を対象とし、容積法及び流速法で湧 水(カー)の流量を測定した注2)

\section{表 1 各湧水地点の観測数}

\begin{tabular}{|c|c|c|c|c|c|c|c|c|c|}
\hline & $\begin{array}{l}\text { (3)xンダカ } \\
\text { 北ーガ- }\end{array}$ & $\begin{array}{l}(6) \text { アラナキ } \\
\text { ガ- }\end{array}$ & 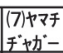 & $\begin{array}{l}(8) \text { ウーシヌ } \\
\text { এカガー }\end{array}$ & $\begin{array}{l}(9) \in+b- \\
\text { 力-ガ- }\end{array}$ & $\begin{array}{l}\text { (11)ふふ心んL } \\
\text { hull }\end{array}$ & $\begin{array}{l}\text { (12)フルチン } \\
\text { ガー }\end{array}$ & (13)於ガー & $\begin{array}{l}(15) \text { チュン } \\
\text { ナーガー }\end{array}$ \\
\hline 既存調查 $\left(\mathrm{N}_{1}\right)$ & 21 & 21 & 6 & 6 & 21 & 6 & 15 & 6 & 21 \\
\hline 独自調查 $\left(\mathrm{N}_{2}\right)$ & 62 & 62 & 52 & 25 & 60 & 23 & 0 & 23 & 0 \\
\hline 総数(N) & 83 & 83 & 58 & 31 & 81 & 29 & 15 & 29 & 21 \\
\hline
\end{tabular}

\section{3-2. 湧水量調査結果からの母湧水量の推定}

独自で行った調查 $\mathrm{N}_{2}$ については、湧水量と直前降水量との相関関係 を分析した。直前降水量は、地下水という特性を考慮して測定直前か ら 1 5 日前までの総降水量の累計值 $\left(\mathrm{D}_{1}, \mathrm{D}_{2}, \mathrm{D}_{3}, \mathrm{D}_{4}, \mathrm{D}_{5}\right)$ を用いた。その 結果、(8) ウーシヌハナガーと (9) ヒャーカーガーでは 0.6 以上の高い 相関関係が確認されたので回帰分析を行って以下の結果を得た注 3$)$ 。

(8) $\mathrm{y}=13.85 \mathrm{x}^{* * *}+455.3^{* * *}\left(\mathrm{R}^{2}=0.67\right)$

(9) $\mathrm{y}=114.24 \mathrm{x}^{* * *}+2235.3^{* * *}\left(\mathrm{R}^{2}=0.63\right)$

$$
\mathrm{y} \text { : 湧水量 } \mathrm{x} \text { : 降水量 } * * * 0.1 \% \text { 有意 }
$$

この二つの湧水口は降水量の影響を受けることから、年間降水量の 95\%值を用いて区間推計を行い注 4$)$ 、その值を回帰式に代入して湧水 量を求めた。その他の湧水口については、正規分布もしくは $\mathrm{t}$ 分布に より $95 \%$ 信頼区間で母湧水量を推計した。その結果、流域別の年間湧 水量は C 流域 (119.3 万 $\mathrm{m}^{3} \leqq \mu_{\mathrm{C}} \leqq 153.4$ 万 $\mathrm{m}^{3}$ )、 $\mathrm{D}$ 流域 (239.8 万 $\mathrm{m}^{3} \leqq \mu_{\mathrm{D}}$ $\leqq 652.9$ 万 $\mathrm{m}^{3}$ )、 $\mathrm{E}$ 流域 $\left(62.7\right.$ 万 $\mathrm{m}^{3} \leqq \mu_{\mathrm{E}} \leqq 86.1$ 万 $\left.\mathrm{m}^{3}\right)$ となる (表 2$) 。$

既存の自然環境調査に対して、測定回数を増やしたことにより、(1) 区間推定の幅が狭まったこと、(2)降水量を考慮できるモデルが組めた ことが本研究の成果である。 
表 2 主な湧水地点における湧水量の推移

\begin{tabular}{|c|c|c|c|c|c|c|c|}
\hline \multicolumn{8}{|c|}{ 主な湧水地点における湧水量の推移(単位 $m^{2} /$ 年) } \\
\hline \multirow{2}{*}{\multicolumn{2}{|c|}{ 湧水名 }} & \multirow{2}{*}{$\begin{array}{c}\text { 宜野湾市調查 } \\
(4 \sim 3) \text { 月合計 }\end{array}$} & \multicolumn{2}{|c|}{ 各湧水地点湧水量 } & \multicolumn{2}{|c|}{ 各流域湧水量 } & \multirow[b]{2}{*}{ 流域名 } \\
\hline & & & 下限 & 上限 & 下限 & 上限 & \\
\hline (1) & シチャヌカー & 238,254 & - & - & \multirow{7}{*}{$1,193,229$} & \multirow{7}{*}{$1,533,716$} & \multirow{7}{*}{ C } \\
\hline (2) & 森の川 & 20,099 & - & - & & & \\
\hline (3) & メンダカリヒーガー & 299,562 & 196,488 & 218,149 & & & \\
\hline (4) & ミジカシガー & 10,249 & - & - & & & \\
\hline (5) & マジキナガー & - & 70,325 & 70,325 & & & \\
\hline (6) & アラナキガー & 657,540 & 654,583 & 969,651 & & & \\
\hline (7) & ヤマチジャガー & 9,607 & 3,231 & 6,989 & & & \\
\hline (8) & ウーシヌハナガー & 136,003 & 189,070 & 194,180 & \multirow{5}{*}{$2,398,130$} & \multirow{5}{*}{$6,529,350$} & \multirow{5}{*}{ D } \\
\hline (9) & ヒャーカーガー & 634,611 & $1,036,600$ & $1,077,845$ & & & \\
\hline (10) & ナイシガー & 140,355 & - & - & & & \\
\hline (11) & ふんしん川 & 140,864 & 86,014 & 128,482 & & & \\
\hline$(12)$ & フルチンガー & $3,246,147$ & 946,091 & $4,988,488$ & & & \\
\hline (13) & ウフガー & 270,072 & 235,254 & 287,633 & \multirow{3}{*}{626,736} & \multirow{3}{*}{861,313} & \multirow{3}{*}{$\mathrm{E}$} \\
\hline (14) & ウブガー & 172,821 & - & - & & & \\
\hline (15) & 丁ュンナーガー & 245,659 & 218,661 & 400,859 & & & \\
\hline (16) & ウシアミシガー & 589,407 & - & - & \multirow{2}{*}{649,852} & \multirow{2}{*}{649,852} & \multirow{2}{*}{ A } \\
\hline (17) & 大謝名メーヌカー & 60,445 & - & - & & & \\
\hline & 年間降水量(mm) & \multicolumn{6}{|c|}{ 1986年-2015年の過去30年におけする年平均降水量95\%信頼区間(1934mm $\leqq \mu \mathrm{P} \leqq 2294 \mathrm{~mm})$} \\
\hline & \multicolumn{7}{|c|}{ ※宜野湾市調查欄は平成16年4月～平成17年3月に宜野湾市によって行われた湧水量調查結果の参考値 } \\
\hline
\end{tabular}

\section{4. 現在の流域別土地利用現況別流出係数を元にした流域別湧水量の 理論值推計}

水収支式は, 一般に次式で表される。

$$
\mathrm{P}=\mathrm{E}+\mathrm{D}+\mathrm{G}
$$

$(P$ : 降水量、 $E$ : 蒸発散量、 $D$ : 地表流出量、 $G$ : 地下浸透量及び涌水量 $)$

本研究では、開発前の理論上の流域別湧水量の推計を行うにあたり、 現状の本地区の土地利用現況及び周辺の既成市街地の土地利用現況 を流域別で(1)滑走路・施設など、(2)芝地、(3)樹林地、(4)烟地に分類し特 定した。年間降水量は 3 章の補注 4) の方法で得られた 2, $114 \mathrm{~mm}$ 用い

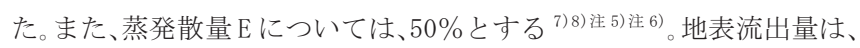
既存調查を参考に注 ${ }^{7)}$ 土地利用別に各地表面の流出係数を設定し((1) 宅地・道路舗装 0.82 、(2)芝地 0.15 、(3)樹林地 0.30 、(4)畑地 0.20 )、これ に各用途の面積を乗じて算出した。

以上で求めた流域別年間湧水量の理論值は $C$ 流域 $\left(\hat{\mu}_{\mathrm{C}}=134.3\right.$ 万 $\left.\mathrm{m}^{3}\right)$ 、 $\mathrm{D}$ 流域 $\left(\hat{\mu}_{\mathrm{D}}=441.7\right.$ 万 $\left.\mathrm{m}^{3}\right) 、 \mathrm{E}$ 流域 $\left(\hat{\mu}_{\mathrm{E}}=220.0\right.$ 万 $\left.\mathrm{m}^{3}\right)$ となる (表 3$)$ 。

表 3 現在の土地利用における開発前の湧水量

\begin{tabular}{|c|c|c|c|c|c|c|c|c|c|c|c|}
\hline 流域名 & 塆找面面科 & 棫内㦀水量 & 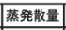 & 土地利用 & 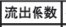 & $\mid$ & 地表整击量 & 地表流山量合计 & 地下浸透昜 & 地下曼透平 & 㴗水量 \\
\hline & गुल & 万囱/年 & 万的年年 & & & 万触 & 万嗝年 & 万的/年 & 万解/年 & & 万光/年 \\
\hline \multirow{2}{*}{ C流域 } & & & & 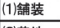 & 2.82 & 60.9 & 52.8 & & & & \multirow{8}{*}{134.3} \\
\hline & {$[124.6$} & 263.4 & 131.7 & (2)位地 & 0.15 & 58.8 & 9.3 & 63.7 & 68.0 & 25.8 & \\
\hline \multirow{3}{*}{ c-1流域 } & & & & 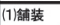 & 2.82 & 39.4 & 34.1 & \multirow{3}{*}{38.6} & \multirow{3}{*}{16.3} & \multirow{3}{*}{14.8} & \\
\hline & 51.9 & 109.7 & 54.9 & (2)㭶地 & 2.15 & $\begin{array}{l}6.3 \\
-5.3\end{array}$ & 1.0 & & & & \\
\hline & & & & & 0.20 & 7.7 & & & & & \\
\hline c-2流域 & 103.9 & 2196 & 109.8 & 这地 & $\begin{array}{l}.3 .15 \\
0.15 \\
\end{array}$ & $\begin{array}{l}832 \\
0.0 \\
0.07\end{array}$ & $\begin{array}{l}2.1 \\
0.0 \\
0.0\end{array}$ & 78.5 & 31.4 & \multirow{2}{*}{14.3} & \\
\hline & & & & & & & & & & & \\
\hline 茜下水 & 43.7 & 92.4 & 46.2 & 这地 & $\frac{.3 .1}{.1 .1}$ & 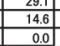 & $\frac{25.2}{2.3}$ & 27.5 & 18.7 & 20.2 & \\
\hline D流域 & 310.2 & 655.8 & 327.9 & 通地 & $\frac{.828}{0.15}$ & $\begin{array}{l}8.35 .8 \\
115.8 \\
\end{array}$ & $\begin{array}{l}\frac{72.5}{18.4} \\
18.4\end{array}$ & 126.0 & 201.9 & 30.8 & \multirow{7}{*}{441.7} \\
\hline \multirow{2}{*}{ D-1流域 } & & 19\%? & & (1) & $\begin{array}{l}2.82 \\
0.15 \\
\end{array}$ & $\frac{148.0}{16.3}$ & $\frac{28.3}{2.6}$ & 410 & 773 & 175 & \\
\hline & & 400.0 & & 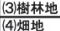 & 2.30 & $\frac{19.8}{223}$ & $\frac{6.3}{47}$ & & 70.0 & & \\
\hline $\begin{array}{l}\text { D-1流 } \\
\text { 湆 }\end{array}$ & 1248 & 2950 & 1425 & 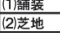 & $\begin{array}{l}0.82 \\
.15 \\
\end{array}$ & $\frac{98.5}{13.6}$ & $\begin{array}{r}85.4 \\
\end{array}$ & 937 & 488 & 171 & \\
\hline & & & & & 0.30 & 124 & $\begin{array}{r}4.0 \\
\end{array}$ & & & & \\
\hline \multirow[t]{2}{*}{ D-2流域 } & 61.7 & 130.4 & 65.2 & 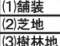 & $\frac{2.8 .}{2.11}$ & $\begin{array}{r}\quad 45.2 \\
1.2 \\
153\end{array}$ & $\begin{array}{r}39.2 \\
0.2 \\
\end{array}$ & \multirow[t]{2}{*}{44.2} & \multirow[t]{2}{*}{21.0} & \multirow[t]{2}{*}{16.1} & \\
\hline & & & & 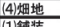 & 0.20 & 00 & & & & & \\
\hline 地下水 & 91.7 & 193.9 & 96.9 & 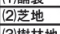 & $\begin{array}{l}.324 \\
0.15 \\
\end{array}$ & $\begin{array}{l}23.3 \\
23.8 \\
\end{array}$ & \begin{tabular}{|l|}
3.1 \\
3.8 \\
\end{tabular} & 38.4 & 58.5 & 30.2 & \multirow{4}{*}{220.0} \\
\hline E流域 & 40.4 & 85.4 & 42.7 & 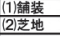 & $\frac{.382}{2.15}$ & $\begin{array}{r}5.4 \\
11.5 \\
\end{array}$ & $\begin{array}{l}4.1 \\
1.8 \\
\end{array}$ & 14.0 & 28.7 & 33.5 & \\
\hline & 341.9 & 722.8 & 361.4 & & 2.15 & $\begin{array}{c}2550 \\
54,3 \\
493\end{array}$ & $\begin{array}{r}: 03.7 .6 \\
8.6 \\
15\end{array}$ & 228.6 & 132.8 & 18.4 & \\
\hline & & & & & & & & & & & \\
\hline
\end{tabular}

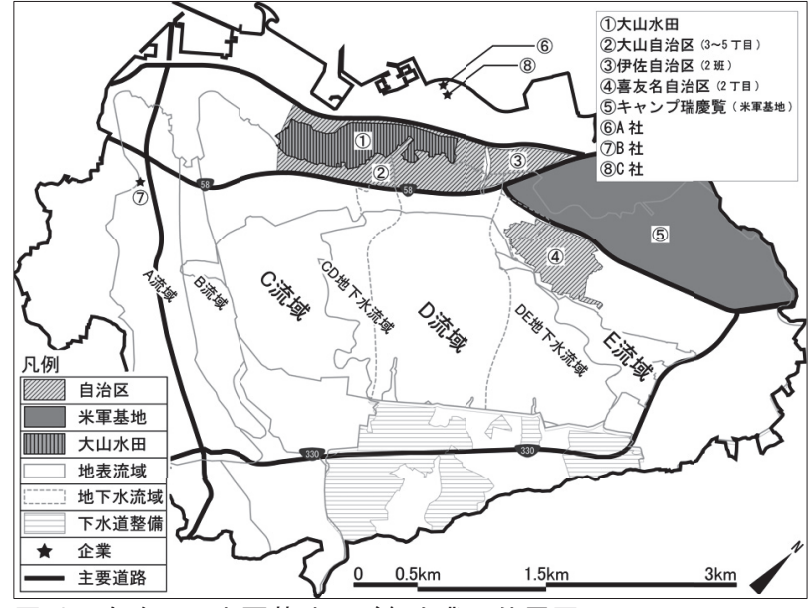

図 3 自治区、米軍基地及び各企業の位置図

5. 小活 : 流域別母湧水量の観測值からの推計値と理論值の適合性か らみた、流出係数及び水収支モデルの妥当性の検討

以上より、C、D 流域において、3-2 の観測值を用いて算出した流域 別母湧水量平均 $95 \%$ 区間推定内に、4 章で算出した水収支モデルを用 いた流域別湧水量の理論值が含まれる事が実証できた注 8$)$ 。この実証 によって、 4 章で用いた各土地利用用途別の流出係数の数值の妥当性、 及び水収支モデルの妥当性が証明された事になる。第一段階の分析で、 流出係数の数值及び水収支モデルが有意となったことから、次章以降 で基地跡地開発前後の土地利用の変化 (基地跡地内の緑地の量や配置) と連動して湧水量がどう変化するかを分析する事が可能となった。

\section{6. 地下水 · 湧水の利用及び将来需要量と供給量への逼迫状況}

\section{6-1. 家庭用・産業用における地下水・湧水の利用状況}

次に需要面からの分析を行う。現在確認されている宜野湾市の地下 水・湧水は、家庭用として喜友名、伊佐自治区がそれぞれ 160 世帯、80 世帯使用しており、主に散水や生活雑用水として利用している注 9)。産 業用では大山水田が市域最大の水需要であり、水田の立地と各農家の 栽培方法で坪当たりの水の使用方法が異なる注 ${ }^{10)}$ 。ヒアリングで得ら れた立地と栽培方法を勘案して需要を算出すると、上流部ではメンダ カリヒーガー(約 18.6 万 $\mathrm{m}^{3} /$ 年) ・アラナキガー(約 63.9 万 $\mathrm{m}^{3} /$ 年) ・フル チンガー (122. 9 万 $\mathrm{m}^{3} /$ 年)、下流部ではフルチンガー (52.4 万 $\mathrm{m}^{3} /$ 年)の 計 257.8 万 $\mathrm{m}^{3} /$ 年である (表 4 )。大山水田 $11 \mathrm{ha}$ の営農は、全て大山・伊佐 自治区に湧き出る湧水で賄われている。又、コンクリート業A社(以下、 $\mathrm{A}$ 社) 及びコンクリート業 $\mathrm{B}$ 社 (以下、 $\mathrm{B}$ 社) では、海砂の除塩やコンクリ 一トの練り混ぜ水として利用が確認され、温泉業 C 社 (以下、C 社)では 施設内のシャワー及び清掃、更にレストランにて飲料水として利用さ れており、利用量は年間 $1.5 \sim 5$ 万 $\mathrm{m}^{3} /$ 年弱である注 ${ }^{11}$ 。大山水田以外の 産業用で約 7 万 $\mathrm{m}^{3} /$ 年、家庭用で約 10 万 $\mathrm{m}^{3} /$ 年とした ${ }^{12)}$ 。

表 4 産業用及び家庭用の地下水・湧水の需要量

\begin{tabular}{|c|c|c|c|c|}
\hline \multicolumn{2}{|c|}{ 地下水利用 } & 取水湧水口 & 需要量(万 $\mathrm{m}^{3} /$ 年)、(件) & 流域 \\
\hline \multirow{6}{*}{ 産業用 } & \multirow{3}{*}{ 大山水田 } & (3)メンダカリヒーガー & 18.60 & $\mathrm{C}$ \\
\hline & & (6)アラナキガー & 63.96 & $\mathrm{c}$ \\
\hline & & (122)フルチンガー & 175.40 & $\mathrm{D}$ \\
\hline & A社 & (13)ウフガー & 0.93 & $\mathrm{E}$ \\
\hline & B社 & (17)大謝名メーヌカー & 1.60 & A \\
\hline & C社 & (13)ウフガー & 4.52 & $\mathrm{E}$ \\
\hline \multirow{2}{*}{ 家庭用 } & 伊佐自治区 & (11)ふふふんしん川 & 80 件 & $\mathrm{D}$ \\
\hline & 喜友名自治区 & (15)チユンナーガー & 160件 & $\mathrm{E}$ \\
\hline
\end{tabular}




\section{6-2. 地下水・湧水の供給量と需要量の関係}

まず、4 章で行った主な湧水地点における母湧水量の推定の理論值 (供給量) と家庭用及び産業用としてヒアリングと実測調査から得ら れた地下水・湧水の需要量との関係について分析を行う。

流域別で地下水・湧水の供給量と需要量との関係を比較すると、C 流域において供給量 ( 134.3 万 $\mathrm{m}^{3} /$ 年) に対する需要量 $\left(83.0\right.$ 万 $\mathrm{m}^{3} /$ 年) の 割合が $62 \%$ と高い值を示す。D 流域においては、大山水田での需要量 が 175.4 万 $\mathrm{m}^{3}$ と水田全体の 7 割の地下水・湧水がフルチンガー (D 流域) からの取水によって賄われているが、供給量 (441. 7 万 $\mathrm{m}^{3} /$ 年) に対する 需要量 $\left(175.4\right.$ 万 $\mathrm{m}^{3} /$ 年) の割合は $40 \%$ とあまり高くはなく、湧水量が豊 富であることがわかる。E流域においては、現在はキャンプ瑞慶覽内の 斜面緑地が残っていることから湧水量も豊富であり、また、企業 2 社及 び家庭用が年間約 $15 \mathrm{j} \mathrm{m}^{3} /$ 年程度の水需要量であるため、供給量 ( 220.0 万 $\mathrm{m}^{3} /$ 年) に対する需要量 $\left(15 \mathrm{~J}^{3} /\right.$ 年) の割合は $7 \%$ となってお り、D 及び $\mathrm{E}$ 流域では地下水供給量が需要量に対して多い(次頁表 6)。

次に、各湧水口別で地下水・湧水の供給量と需要量の関係について の比較と月単位での水収支結果の分析を行う。

まず、各湧水口別で地下水・湧水の供給量と需要量の関係を比較す ると、C 流域の(3)メンダカリヒーガーと(6)アラナキガーにおいては、供 給量に対する需要量の割合がそれぞれ $91 \%$ ((3)メンダカリヒーガー)、 $80 \%$ ((6)アラナキガー) となっており、供給量に需要量が逼迫する(次 頁図 4 左側)。

更に過去 30 年間降水量を用いた月単位での水収支結果の分析より、 月平均降水量の場合、冬期は 11 月 3 月、夏期は 7 月に渇水期となり 水不足が生じる。冬期(11〜3 月)の渇水期については、営農地の面積 や農家側が対策を講じることにより、水不足は回避できるが、夏期 の 7 月に渴水が生じると地下水需要量が増加するため水不足は深刻 である(表 5)。

また、10 年に 1 度の渴水リスクの場合はいずれの月においても、 推計した需要量より供給量が下回る結果となった。

ヒアリングによると、この二つの湧水口では、渴水期及び水需要の 増加する夏期には、開発前の現在でも取水をめぐって農家同士でいさ かいがあるとされており、この事実とも数值が合致する。

以上の事から、(3)メンダカリヒーガーと(6)アラナキガーの存在する C 流域の緑地量については、特に今後の開発で地下水涵養のための緑 地について慎重な配慮が求められることが明らかとなった。

\section{表 5 C 流域における湧水口別の月別水収支}

\begin{tabular}{|c|c|c|c|c|c|c|c|c|c|c|c|c|c|c|}
\hline \multicolumn{2}{|c|}{ 月 } & 1 & 2 & 3 & 4 & 5 & 6 & 7 & 8 & 9 & 10 & 11 & 12 & $\begin{array}{l}\text { 年間 } \\
\end{array}$ \\
\hline \multirow{2}{*}{$\begin{array}{c}\text { 過去30年 } \\
\text { 月別降水 } \\
\text { 量 }(\mathrm{mm})\end{array}$} & 平均 & 109 & 119 & 156 & 180 & 278 & 265 & 152 & 227 & 239 & 167 & 125 & 95 & 2114 \\
\hline & 標準偏差 & 54 & 88 & 77 & 102 & 147 & 164 & 134 & 171 & 167 & 121 & 76 & 61 & 481 \\
\hline \multicolumn{2}{|c|}{$\begin{array}{c}10 \text { 年に1度の } \\
\text { 渇水降水量 }\end{array}$} & 59.7 & 39.2 & 75.5 & 72.8 & 87 & 48.4 & 20.8 & 73.2 & 45.6 & 18 & 44.2 & 21.5 & 1527 \\
\hline \multicolumn{2}{|c|}{$\begin{array}{l}\text { C流域渴水時 } \\
\text { 湧水量 }\left(\text { 万 } \text { ( }^{3}\right)\end{array}$} & 3.8 & 2.5 & 4.8 & 4.6 & 5.5 & 3.1 & 1.3 & 4.7 & 2.9 & 1.1 & 2.8 & 1.4 & 97.2 \\
\hline \multicolumn{2}{|c|}{ 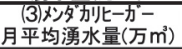 } & 1.05 & 1.16 & 1.51 & 1.73 & 2.69 & 2.55 & 1.47 & 2.19 & 2.31 & 1.61 & 1.20 & 0.91 & 20.39 \\
\hline \multicolumn{2}{|c|}{ 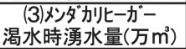 } & 0.58 & 0.38 & 0.73 & 0.70 & 0.84 & 0.47 & 0.20 & 0.71 & 0.44 & 0.17 & 0.43 & 0.21 & 5.85 \\
\hline \multicolumn{2}{|c|}{ 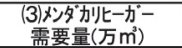 } & 1.51 & 1.51 & 1.55 & 1.55 & 1.55 & 1.55 & 1.59 & 1.59 & 1.59 & 1.55 & 1.55 & 1.51 & 18.60 \\
\hline \multicolumn{2}{|c|}{ 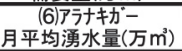 } & 4.11 & 4.53 & 5.90 & 6.79 & 10.54 & 10.01 & 5.78 & 8.58 & 9.05 & 6.31 & 4.71 & 3.57 & \begin{tabular}{|l|}
79.87 \\
\end{tabular} \\
\hline \multicolumn{2}{|c|}{ 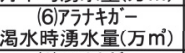 } & 2.26 & 1.49 & 2.86 & 2.74 & 3.28 & 1.85 & 0.77 & 2.80 & 1.73 & 0.66 & 1.67 & 0.83 & 22.93 \\
\hline \multicolumn{2}{|c|}{$\begin{array}{c}\text { (6)アラ゙テキガ- } \\
\text { 需要量(万方 } \\
\end{array}$} & 4.64 & 4.64 & 5.33 & 5.33 & 5.33 & 5.33 & 6.02 & 6.02 & 6.02 & 5.33 & 5.33 & 4.64 & 63.96 \\
\hline
\end{tabular}

\section{6-3 今後の産業継続意向等と将来需要量}

$\mathrm{A}$ 社、 $\mathrm{B}$ 社、 $\mathrm{C}$ 社とも産業利用として地下水湧水を利用しており、今後 も継続を考えている。

地下水の最大需要である市街化区域内農地の大山水田でも、ヒアリ ングによると専業農家の営農意欲・継続意欲も高く、市でも農住組合 区画整理を検討するなど存続に対しては肯定的である。しかし、長期 的には後継者の問題もあることから市の検討では、現状の大山水田 の営農面積約 11 ha が将来的に区画整理事業により約 5 h に縮小寸る 計画がなされていたので、A〜C 社は存続、大山水田は 5ha の水田を 営むことを今後の水需要の最低量として前提をした。家庭用は、現況 と同等量とした。

\section{7. 現行基地跡地利用構想の課題と水需給構造を踏まえた提案}

\section{7-1.「中間とりまとめ」における水収支モデル}

4 章と同様に GIS を用いて、「中間とりまとめ」で示されている土地 利用計画が実施された場合の地下水への影響を作成した水収支モデ ルを用いて推定した。その結果、C 流域においては開発後、緑被率が減 少することにより、湧水量が 100.0 万 $\mathrm{m}^{3}$ / 年まで減少し、開発後の供給 量に対する現在需要量の割合は $83 \%$ と高い值を示すことが明らかと なった (次頁表 7)。更に、各湧水口別で供給量と需要量を比較すると (3) メンダカリヒーガー及び(6)アラナキガーにおいて需要量が供給量を 上回る結果となった(次頁図 5 左側)。なお、D 流域においては、開発 後も地表水が洞窟に伏流するため湧水量は増加する。

\section{7-2. 流域別の湧水量を担保する基地跡地内緑地配置の提案}

\section{7-2-1. 水収支から見た流域別緑地量の計画条件の整理}

6 章の分析結果より、現在の家庭用及び産業用における水需要量を 考慮すると、開発後、最低限確保しなければならない湧水量は C 流域 123.1 万 $\mathrm{m}^{3} /$ 年、 $\mathrm{D}$ 流域 472.1 万 $\mathrm{m}^{3} /$ 年、 $\mathrm{E}$ 流域 172.8 万 $\mathrm{m}^{3} /$ 年 (次頁表 9 (A) と水需要量と水収支結果より推計される注 ${ }^{13)}$ 。

流域毎の雨水排水平面図から雨水排水特性では、D 流域は開発後 も地表水が洞窟に伏流する可能性があり緑地による地下浸透のみに よって供給量が作用される状況ではない。しかし、C 流域においては地 表水の洞窟への伏流がないため、緑地による地下浸透を見込まなけれ ばならない。つまり C 流域では、開発後の緑地量の減少により、湧水量 が減少し、産業に影響を及ぼす危険性が考えられるので配慮が求めら れる。

\section{7-2-2. 中間とりまとめの流域別緑地量の計画条件の整理}

中間とりまとめにおける緑地計画の方針として、(1)自然度が高い 緑地の保全、(2)文化財周辺の緑地の保全、(3)地下水脈上の緑地の保 全、(4)広場的緑地の創出がある。そのうち、(1)～(3)は樹林地を含め た重要植生として位置付けられており、配置の移動ができない緑地 である(図 4 6 のドット)。重要植生は流域別に C 流域 11.9 万 $\mathrm{m}^{2} 、 \mathrm{D}$ 流域 39.7 万 $\mathrm{m}^{2} 、 \mathrm{E}$ 流域 12.8 万 $\mathrm{m}^{2}$ である(表 9 B) 。重要植生を除いた 再配分可能な広場的緑地は C 流域 19.4 万 $\mathrm{m}^{2} 、 \mathrm{D}$ 流域 41.3 万 $\mathrm{m}^{2} 、 \mathrm{E}$ 流域 11.0 万 $\mathrm{m}^{2}$ (表 9@) である。

中間とりまとめの中で示された緑地計画の各流域の総量としての 緑地量は、C 流域 31.3 万 $\mathrm{m}^{2} 、 \mathrm{D}$ 流域 81.0 万 $\mathrm{m}^{2} 、 \mathrm{E}$ 流域 23.8 万 $\mathrm{m}^{2}$ (表 9(B+(C) となっており、これら地下水涵養としての緑地計画における 湧水量は C 流域 100.0 万 $\mathrm{m}^{3} /$ 年、D 流域 478.2 万 $\mathrm{m}^{3} /$ 年、 E 流域 172.8 万 $\mathrm{m}^{3} /$ 年 (表 9D) と水収支結果より推計される。この結果より、7-2-1 


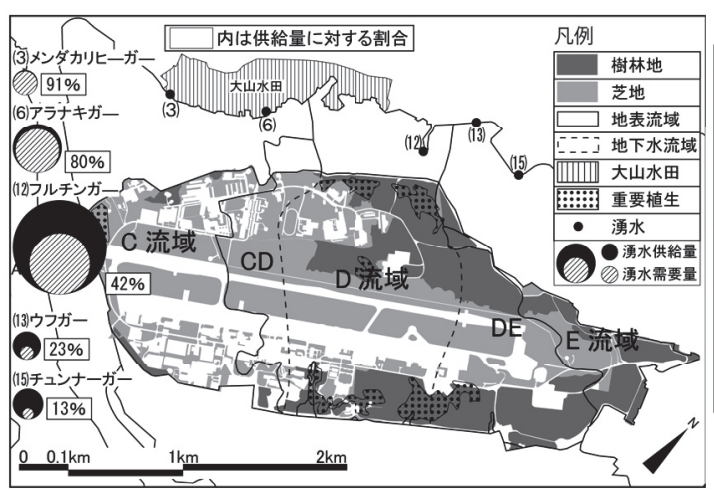

表 6 現況土地利用における水収支

\begin{tabular}{|c|c|c|c|c|c|c|c|c|c|c|c|c|}
\hline 流域名 & 流域面積 & 域内降水量 & $\begin{array}{l}\text { 蒸発散量 } \\
\end{array}$ & 土地利用 & 流出係数 & \begin{tabular}{|l|} 
各面皘 \\
\end{tabular} & 地表流出量 & 地表流出量合計 & 地下漫透量 & 地下浸透率 & 賈水量 & 需要量 \\
\hline & 万m & 万解/年 & 万 $\mathrm{m}^{3} /$ 年 & & & 万m & 万 $\mathrm{m} /$ 年 & 万甶/年 & 万角/年 & $\%$ & 万角/年 & 万烈/年 \\
\hline C流㖪 & 124.6 & 263.4 & 131.7 & $\begin{array}{l}\text { (1)谽装 } \\
\text { (2) 地 } \\
\text { (2) }\end{array}$ & $\begin{array}{ll}0.82 \\
0.15\end{array}$ & \begin{tabular}{|l|}
60.9 \\
58.8 \\
49
\end{tabular} & $\begin{array}{r}52.8 \\
9.3 \\
16\end{array}$ & 63.7 & 68.0 & 25.8 & \multirow{3}{*}{134.3} & \multirow{3}{*}{$\begin{array}{c}83.0 \\
(62 \%)\end{array}$} \\
\hline & & & & $\begin{array}{l}\text { (3)樹林地 } \\
\text { (1)结装 }\end{array}$ & $\begin{array}{l}0.30 \\
0.82\end{array}$ & \begin{tabular}{|r|}
4.9 \\
291
\end{tabular} & $\begin{array}{r}1.6 \\
252\end{array}$ & & & & & \\
\hline 地下水 & 43.7 & 92.4 & 46.2 & $\begin{array}{l}\text { (2)芝地 } \\
\text { (3)挃林地 }\end{array}$ & $\begin{array}{l}0.15 \\
0.30\end{array}$ & $\begin{array}{r}29.1 \\
14.6 \\
0.0\end{array}$ & $\begin{array}{r}r .4 \\
2.3 \\
0.0\end{array}$ & 27.5 & 18.7 & 20.2 & & \\
\hline D流域 & 174.8 & 369.5 & 184.8 & 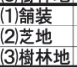 & $\begin{array}{l}0.82 \\
0.15 \\
0.30\end{array}$ & \begin{tabular}{|l|}
30.7 \\
77.4 \\
66.7 \\
\end{tabular} & \begin{tabular}{l|l}
26.6 \\
12.3 \\
21.2
\end{tabular} & 60.0 & 124.7 & 33.7 & 441.7 & $\begin{array}{r}175.4 \\
(40 \%)\end{array}$ \\
\hline $\begin{array}{l}\mathrm{DE} \\
\text { 地下水 } \\
\text { 莜域 }\end{array}$ & 91.7 & 193.9 & 96.9 & $\begin{array}{l}\text { (1)信装 } \\
\text { (2)芝地 } \\
\text { (3) }\end{array}$ & $\begin{array}{l}0.82 \\
0.15 \\
0.30\end{array}$ & \begin{tabular}{|l|}
23.9 \\
23.8 \\
44.0
\end{tabular} & \begin{tabular}{r|}
20.7 \\
3.8 \\
140
\end{tabular} & 38.4 & 58.5 & 30.2 & \multirow[b]{2}{*}{220.0} & \multirow{2}{*}{$\begin{array}{c}15.0 \\
(7 \%)\end{array}$} \\
\hline E流域 & 40.4 & 85.4 & 42.7 & 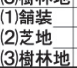 & $\begin{array}{l}0.82 \\
0.15 \\
0.30\end{array}$ & \begin{tabular}{|r|}
5.4 \\
11.5 \\
23.5 \\
\end{tabular} & $\begin{array}{l}4.7 \\
1.8 \\
7.5\end{array}$ & 14.0 & 28.7 & 33.5 & & \\
\hline
\end{tabular}

図 4 現況の土地利用

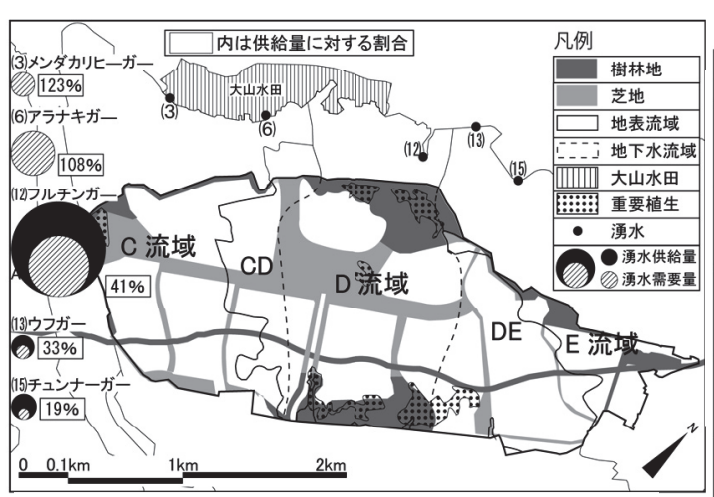

図 5 中間とりまとめの土地利用計画

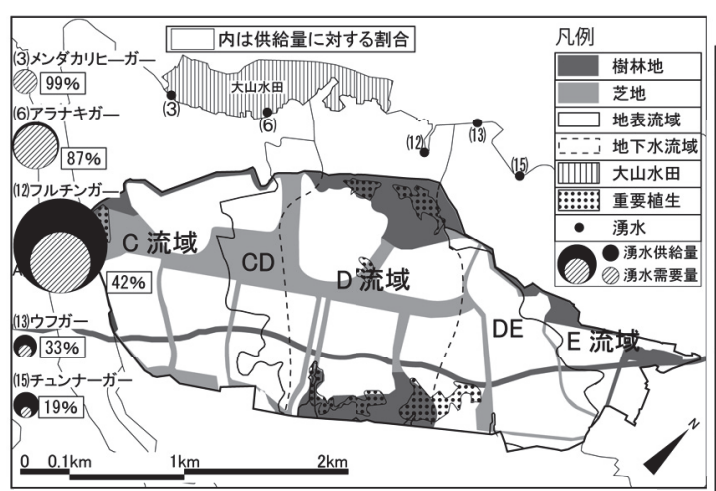

図 6 本研究室提案の緑地計画

\begin{tabular}{|c|c|c|c|c|c|c|c|c|c|c|c|c|}
\hline 洴域各 & 流域面稓 & 域内㦀水量 & 器䋃散量 & +地利用 & 流州俰数 & 各面精 & $\mid$\begin{tabular}{|c|} 
地素流州量 \\
\end{tabular} & 地素流此量会会十 & 地下漫㴡量 & 地下漫悉里 & 洒水量 & $\begin{array}{l}\text { 需要量 } \\
\end{array}$ \\
\hline & 万m & 万尚/年 & 万尚/年 & & & 万m & 万色/年 & 万的/年 & 万min/年 & $\%$ & 万融/年 & 万min/年 \\
\hline c流域 & 124.6 & 263.4 & 131.7 & 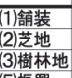 & $\begin{array}{l}0.82 \\
0.15 \\
0.30\end{array}$ & $\begin{array}{l}63.7 \\
11.0 \\
11.3 \\
18.3\end{array}$ & $\begin{array}{r}55.2 \\
1.7 \\
3.6 \\
\end{array}$ & 94.0 & 37.7 & 14.3 & \multirow[b]{2}{*}{$\begin{array}{l}100.0 \\
\left(\aleph_{1}\right)\end{array}$} & \multirow[b]{2}{*}{$\begin{array}{l}83.0 \\
(83 \%)\end{array}$} \\
\hline $\begin{array}{l}\text { 地 } \\
\text { 地下水 }\end{array}$ & 43.7 & 92.4 & 46.2 & 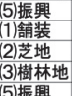 & $\begin{array}{l}0.82 \\
0.82 \\
0.15 \\
0.30\end{array}$ & $\begin{array}{r}38.6 \\
16.6 \\
8.4 \\
0.6\end{array}$ & $\begin{array}{r}33.5 \\
14.4 \\
1.3 \\
0.2 \\
15.7\end{array}$ & 31.6 & 14.6 & 15.8 & & \\
\hline D流域 & 174.8 & 369.5 & 184.8 & 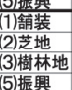 & $\begin{array}{l}.82 \\
0.82 \\
0.15 \\
0.30 \\
0.82\end{array}$ & $\begin{array}{l}8.1 \\
58.3 \\
41.3 \\
39.7 \\
35.5\end{array}$ & $\begin{array}{r}50.1 \\
50.5 \\
6.5 \\
12.6 \\
30.8\end{array}$ & 100.4 & 84.3 & 22.8 & $\begin{array}{l}4782 \\
\left(\Psi_{2}\right)\end{array}$ & $\begin{array}{c}17545) \\
(37 \%)\end{array}$ \\
\hline $\begin{array}{l}\text { 地 } \\
\text { 地下水流域 }\end{array}$ & 91.7 & 193.9 & 96.9 & 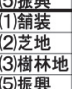 & $\begin{array}{l}0.82 \\
0.82 \\
0.15 \\
0.30\end{array}$ & 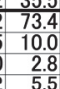 & $\begin{array}{r}r 3.8 \\
63.6 \\
1.6 \\
0.9 \\
4.8\end{array}$ & 70.9 & 26.1 & 13.4 & \multirow{2}{*}{$\begin{array}{l}172.8 \\
\left(\aleph_{3}\right)\end{array}$} & \multirow{2}{*}{$\begin{array}{l}15.0 \\
(9 \%)\end{array}$} \\
\hline E流域 & 40.4 & 85.4 & 42.7 & 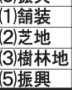 & $\begin{array}{l}0.82 \\
0.15 \\
0.30 \\
0.82\end{array}$ & $\begin{array}{r}28.2 \\
1.0 \\
10.0 \\
1.2\end{array}$ & $\begin{array}{r}24.4 \\
0.2 \\
3.2 \\
1.0\end{array}$ & 28.8 & 13.9 & 16.3 & & \\
\hline
\end{tabular}

表 8 本研究室提案における水収支

\begin{tabular}{|c|c|c|c|c|c|c|c|c|c|c|c|c|}
\hline 流域名 & 流城面賏 & 域内降水量 & 蒸発散量 & 土地利用 & 流出俰数 & 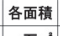 & 地表表去是 & 地表流出量合計 & 地下漫透量 & 地下浸透事 & 湮水量 & 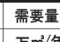 \\
\hline & & & & & & 万的 & 万m/2/年 & & & $\%$ & & \\
\hline C流域 & 124.6 & 263.4 & 131.7 & 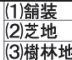 & & \begin{tabular}{|l}
61.7 \\
35.0 \\
11.3
\end{tabular} & $\begin{array}{r}53.5 \\
5.5 \\
3.6\end{array}$ & 77.0 & 54.7 & 20.8 & \multirow{3}{*}{$\begin{array}{l}123.1 \\
\left(\varkappa_{1}\right)\end{array}$} & \multirow{3}{*}{$\begin{array}{r}83.0 \\
667 \%\end{array}$} \\
\hline & & & & 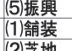 & $\begin{array}{l}0.82 \\
0.82 \\
0.82\end{array}$ & $\begin{array}{l}16.6 \\
16.6\end{array}$ & $\begin{array}{r}14.4 \\
14.4 \\
3.7\end{array}$ & & & & & \\
\hline 地恕下水 & 43.7 & 92.4 & 46.2 & 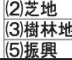 & $\begin{array}{r}0.15 \\
0.30 \\
0.82\end{array}$ & \begin{tabular}{|l}
17.0 \\
0.6 \\
9.5
\end{tabular} & $\begin{array}{l}2.7 \\
0.2 \\
8.2\end{array}$ & 25.5 & 20.7 & 22.4 & & \\
\hline D流域 & 174.8 & 369.5 & 184.8 & 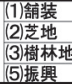 & $\begin{array}{l}0.82 \\
0.15 \\
0.30 \\
0.82\end{array}$ & \begin{tabular}{|l}
58.3 \\
13.0 \\
39.7 \\
63.8
\end{tabular} & $\begin{array}{r}50.5 \\
2.1 \\
12.6 \\
55.3\end{array}$ & 120.5 & 64.3 & 17.4 & $\begin{array}{l}472.1 \\
\left(\aleph_{2}\right)\end{array}$ & $\begin{array}{c}175.4 \\
(37 \%)\end{array}$ \\
\hline 地 & 91.7 & 193.9 & 96.9 & 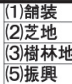 & $\begin{array}{l}0.82 \\
0.15 \\
0.30 \\
0.82\end{array}$ & $\begin{array}{r}73.4 \\
10.0 \\
2.8 \\
5.5\end{array}$ & $\begin{array}{r}63.6 \\
1.6 \\
0.9 \\
4.8\end{array}$ & 70.9 & 26.1 & 13.4 & \multirow{2}{*}{$\begin{array}{l}172.8 \\
\left(\aleph_{3}\right)\end{array}$} & \multirow{2}{*}{$\begin{array}{l}15.0 \\
(9 \%)\end{array}$} \\
\hline E流域 & 40.4 & 85.4 & 42.7 & 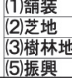 & $\begin{array}{l}0.82 \\
0.15 \\
0.30 \\
0.82\end{array}$ & $\begin{array}{r}28.2 \\
1.0 \\
10.0 \\
1.2\end{array}$ & $\begin{array}{r}24.4 \\
0.2 \\
3.2 \\
1.0\end{array}$ & 28.8 & 13.9 & 16.3 & & \\
\hline
\end{tabular}

※1、※2、※3については、それぞれ(※1 C-1、C-2 流域)、( ※2 D-1、D-2 流域)、(※3 E-1 流域)の地下浸透量を含み 各流域の漓水量に加算して算出を行っている。
表 9 流域別の地下浸透量及び項目別緑地量

\begin{tabular}{|c|c|c|c|c|}
\hline & C流域 & D流域 & E流域 \\
\hline 計画の条件 & (A) 地下浸透量(万min/年) & 123.1 & 472.1 & 172.8 \\
\hline \multirow{4}{*}{ 中間とりまとめ } & (B) 重要植生(万m²) & 11.9 & 39.7 & 12.8 \\
\hline & (c) 広場的緑地のみ(万 $\left.\mathrm{m}^{2}\right)$ & 19.4 & 41.3 & 11.0 \\
\hline & (B)+(C)総緑地量(万的) & 31.3 & 81.0 & 23.8 \\
\hline & (D) 地下浸透量(万光) & 100.0 & 478.2 & 172.8 \\
\hline \multirow{3}{*}{ 研究室提案 } & (E) 広場的緑地のみ(万 $\left.\mathrm{m}^{2}\right)$ & 52.0 & 13.0 & 11.0 \\
\hline & (B)+(E)総緑地量(万 $\left.m^{2}\right)$ & 03.9 & 52.7 & 23.8 \\
\hline & () 地下浸透量(万 $\mathrm{m}^{3} /$ 年) & 123.1 & 472.1 & 172.8 \\
\hline \multicolumn{2}{|c|}{ (E)-(C)不足分の緑地量(万m²) } & 32.6 & - & - \\
\hline
\end{tabular}

で述べた計画条件 (表 9®) と比較すると、C 流域で湧水量が不足して いることが明らかになった。

\section{7-2-3. 流域別の湧水量を担保する緑地配置及び緑地量の提案}

7-2-1 及び 7-2-2 より、本研究における緑地計画の提案条件とし て(1)開発後、C 流域の水需要を満たす湧水量を確保しなければなら ないこと、(2)中間とりまとめの中で示された重要植生の保全が挙げ られる。
提案条件(1)、(2)を踏まえた上で、流域別の確保しなければならな い広場的緑地の緑地量は、C 流域 52 万 $\mathrm{m}^{2} 、 \mathrm{D}$ 流域 13 万 $\mathrm{m}^{2} 、 \mathrm{E}$ 流域 11 万 $\mathrm{m}^{2}$ (表 9 () $)$ と水収支結果より推計される。

中間とりまとめの中で計画された広場的緑地の緑地量と比較する と C 流域において約 33 万 $\mathrm{m}^{2}$ (表 9®-(C) の緑地が不足することが明 らかになった。

以上のことより、C 流域の水需要量を満たす地下水涵養を考慮し た緑地計画として、重要植生を除いた再配分可能な広場的緑地につ いて湧水量の豊富な D 流域より C 及び $\mathrm{CD}$ 地下水流域への緑地量の再 配分を行う必要がある。

再配分緑地については、「中間とりまとめ」で示された緑地計画の 内、配置を移動できる可能性が残る広場的利用を想定した緑地量の中 から再配分量と配置を検討注 ${ }^{14)}$ L、D 流域より 28.3 万 $\mathrm{m}^{2}$ の緑地を C 及 び $\mathrm{CD}$ 地下水流域に再配分した。さらに、C 及び $\mathrm{CD}$ 地下水流域の土 地利用用途別流出係数の高い振興ゾーン及び舗装・道路の 4.3 万 $\mathrm{m}^{2}$ 
を地下水涵養緑地(芝地) として整備し、合計で C 流域に新たに約 33 万 $\mathrm{m}^{2}$ の緑地を広場的緑地として整備した(図 6)。

現状並みの利用をなんとか満たす量を確保できた注 15) ことから、開 発前の現在でも取水をめぐりいさかいが確認されているC流域のメン ダカリヒーガー及びアラナキガーについて、一定程度の計画配慮がで きた。今後の長期的な紛争の未然防止として、本検討は有意義である。

8. 行政、地権者、市民、計画策定業務受注コンサルタントと大学研 究室のアクションリサーチの経緯と成果

本研究では、まず初めに研究室で既存研究及び基礎調査の整理を 行った。その後は、独自の調查を進めながら県及び市の行政機関や地 権者(地主会)、市民代表(以下 $\mathrm{NBM}^{\text {注 }}{ }^{16}$ ) ) 意見交換を行いながら、(1) 〜9のプロセスで本研究を進めてきた(表 10)。(1)研究室から現在の 地下水・湧水について市に共同調查の打診を行ったが、体制が整わな かったため、研究室独自で流量実測調查及び地下水・湧水需要量算出 のためのヒアリングを行った(H27.8)。(2)著者らと NBM とで意見交 換会を行い、宜野湾市の産業の維持及び文化財である湧水の保全の 必要性について NBM の方向性と一致することを確認した(H27.9)。 (3)第 1 回若手地主会との意見交換会を行い、需要面から見た緑地計 画の必要性について理解と評価を得た(H27.10)。(4)協議及び意見交 換会と並行して進めてきた需要量ヒアリング調查より途中段階とし ての、水需要の概算を行い、平成 27 年度普天間飛行場跡地利用計画 策定有識者検討会議第 1 回文化財・自然環境部会(以下、委員会)にお いて水需要から見た水源涵養としての総緑地量の妥当性を検証寸る 必要性について提案を行った(H27.11)。(5)第 2 回若手地主会との意 見交換会を行った。参加者した農業者からの指摘により、大山水田で の水需要量の算出では、立地・栽培方法・取水源で場合分けを行い、算 出する必要があることがわかった(H27.11)。(6)速報值で計算し始め た大山水田での水需要量が相当量となることから、水源涵養のため には基地跡地内の総量としての緑地量の確保の検討ではなく、より 具体に基地跡地内の各流域別及び各湧水口別の緑地量の算出が必要 であることが予測された。流域別の湧水量の確保を目的とした場合、 基地跡地内の緑地配置計画と連動するため、行政の検討計画の進捗 に遅れることなく、調查結果の早急な還元が求められた。そこで、 県・市・コンサルタント及び研究室で事前学習の場の設置を要請し た(H27.12)。(7)水需要及び開発前後における水収支モデルによる試 算結果より、流域毎の水需要の検討が必要であることが明らかにな った。これらの結果については県及び市、コンサルタントと流域別の 水収支及び流出係数の妥当性についての検討勉強会を行い、独自調 查から得られた結果に理解と評価が得られた(H28.1)。8第 2 回委員 会では、研究室の独自調査と作成した水収支モデル試算結果より、供 給量に需要量が逼迫することから流域毎の緑地量の検討及び緑地量 の再配分の必要性について主張し、正式な委員会参考資料として分 析結果の提供を行い、委員会の場でも審議として取り上げられた。 (9) その結果、今後の跡地計画の検討事項として水収支から見た流域 別の緑地量及び緑地配置の検討の方針が文言として明記された。

本研究のアクションリサーチとしての成果は、行政の跡地利用計 画の基本構想の段階で、土地利用計画に対して水収支という合理的 な指標を持って開発前後の土地利用変化による影響を考慮すること の必要性を示せたこと、及び県や市と協調的な関係を保ちながら調
查結果を還元することにより、それを公的な計画方針の中に位置づ けることができたことである。更に地域の資源である湧水の保全や 今後の地域産業の継続の可能性を担保できたことは、大学での研究 の地域還元として大きな成果である。

表 10 水収支モデル検討プロセス

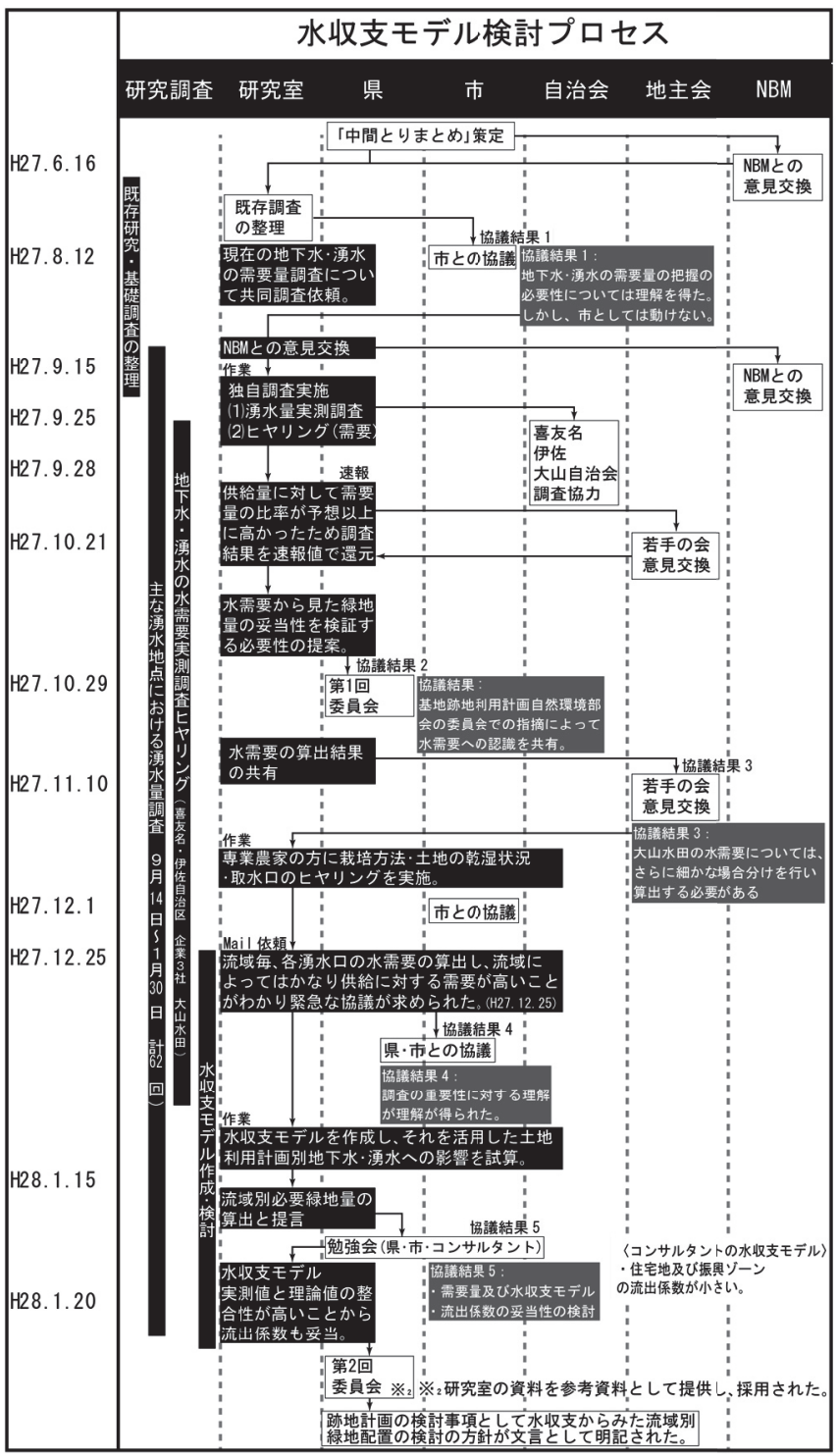

\section{9. 総括 : 本研究の成果と今後の課題}

本研究の成果は以下の点である。(1)本研究の調查により湧水量と 降水量の関係について統計的に有意な回帰式が組めた事、(2)(1)で観 測された湧水量を用いた流域湧水量の母平均推定の精度が上がった 事及び水収支モデルで得られた理論值と適合した事から開発後の土 地利用変化により流域湧水量がどのように変化するかについて土地 利用計画と連動して分析する事が可能になった事、(3)田芋農家の水 利用が明らかになった事、それにより、湧水口の中でも需要量が供給 量に逼迫している湧水口があり、基地跡地の開発で現在の利用が大 きく妨げられる危険性がある事を示せた事、(4)(3)の課題に対して「中 間とりまとめ」までの検討経緯を踏まえながら実現可能な範囲で緑 
地を再配分寸ることにより保全の手だてを提案できた事、(5)行政や 地権者・市民及びコンサルタントと建設的な関係性を保って研究を 進め、調査結果を報告し、改善の提案をしながらともに議論する場を もうけた事により、今後の跡地利用計画の重要な検討事項として位 置づけられた事、があげられる。

今後の課題として、流域別に水収支を算出寸るにあたり、 $\mathrm{E}$ 流域に おける米軍基地内(キャンプ瑞慶覧内)の立入が困難な為、主な湧水 地点の流量調査が実施できていない。 $\mathrm{E}$ 流域の水収支モデルの妥当 性について検討を行うためにも公的な調查が望まれる。また、大山水 田の水需要量については、本研究対象の専業農家だけでなく、兼業農 家を含めてヒアリング対象を増やし、栽培方法及び取水口を明確に することで、各湧水口で賄える範囲を明らかにし、より実態に近づけ ることが求められる。

\section{謝辞}

本研究は、行政や地権者をはじめ調查対象となった多くの方々の 御協力により研究を遂行することができました。この場を借りて、 深く感謝申し上げます。なお、本研究は JSPS 科研費・若手研究 B (課 題名：亜熱帯型環境共生住宅地の土地利用規制に関する研究一沖縄 らしい基地跡地開発に向けて、課題番号 24710168）の助成を受けた ものです。

\section{参考文献}

1) 沖縄県、宜野湾市：全体計画の中間とりまとめ, 2013.3

2) 宜野湾市史編集委員: 宜野湾市史第 9 巻資料編 8 自然, 沖縄県宜野湾市教 育委員会文化課，2000. 3

3) 宜野湾市: 平成 18 年度宜野湾市自然環境調査報告書, 2007.3 4) 宜野湾市: 平成 22 年度宜野湾市自然環境調査報告書, 2011.3 5) 宜野湾市: 平成 24 年度宜野湾市自然環境調査報告書, 2013.3 6) 宜野湾市: 平成 25 年度宜野湾市自然環境調査報告書, 2014.3

7) 高里良政・古川博恭・黒田登美雄：人工的構造物による琉球石灰岩地域の 地下水収支の変化一那覇市首里の琉球石灰岩ブロックを例として一, 琉球 大学理学部紀要 (47), p159-177, 1989.3

8) 近藤純正 : 蒸発散量と降水量の気候学的関係-研究の指針-, 天気, vol45-4, 日本気象学会 pp23-31, 1998

\section{注}

注 1）既存の行政の調査報告書では、月に 1 回短時間の流量調査結果を日換算し、 さらに日換算值を当月湧水量として月換算值を算出し、その後各月の月流 量を総和して年間湧水量として推計している。測定時間の短さ及び換算の 回数の多さから、測定日の変動誤差を受けやすい手法である。また、湧水 口によっては月別の湧水量に大きな差が記録されているものもあった。そ のため、より精度を高めるために、過去の調査報告書の月湧水量測定日と 測定日直前から 5 日前までの降水量を気象庁のデータで確認し、直前降水 量との相関関係から補正が行えないか検討したが、有意な相関が見られな かった。現地調査では、降雨後に湧水量が増えることがいくつかの湧水の 現地調査で確認されている事、及び過去の調査日直前にも降水量の多い日 があった事が確認された事から、既存の調査データではなく独自に湧水量 の計測を行う必要性が確認された。

注 2）フルチンガーは現在も水田での利用が高いが、地下の雨水排水溝と連結 したボックスカルバート内に存在する湧水であり、通常施錠されており立 ち入りできない。さらに、降雨後は急速に水量が増し、過去に死亡事故等 もあったことから立ち入っての調査が不可能である。

注 3）気象庁が公表する過去のアメダスデータより、それぞれの調査日において 5 日前までの降水量を 1〜 5 日閒累計に分類し、流量と比較して相関関係の 分析を行った。有意な相関が見られたものについて、回帰分析を行ったが、 決定係数が 0.6 を超えているのはウーシヌハナガーとヒャーカーガーの 2 地点のみであった。相関が見られなかったものは、湧水量の母平均を求める ために信頼区間 $95 \%$ で流量を算出し、ウーシヌハナガーとヒャーカーガー
に関しては降水量も考慮して年間の流量の補正を行った(図補 $1 、 2)$ 。ヒャ 一カーガーは現地調査でも降雨後の湧水量増大が確認されており、より実 態に近い。

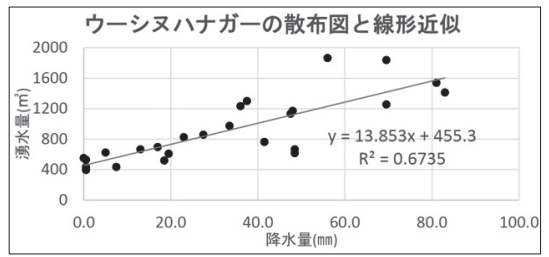

図 補 1 ウーシヌハナガーの散布図と線形近似式

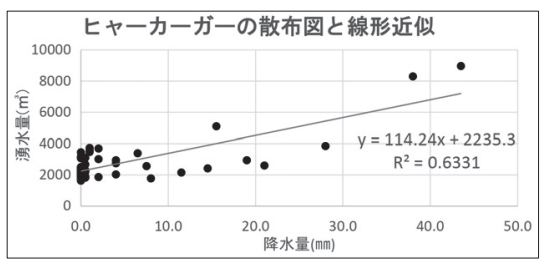

図補 2 ヒャーカーガーの散布図と線形近似式

注 4）年間降水量については, 沖縄気象台のデータを用いて、過去 30 年分の沖 縄市胡屋の気象データから平均值及び $95 \%$ 信頼区間を用いた。その結果は、 $X$ 平均 $=2114 \mathrm{~mm}$ で、95\%信頼区間は $1934 \mathrm{~mm} \leqq \mu \leqq 2294 \mathrm{~mm}$ である。

注 5) 蒸発散量については実測調査が難しいため、高里ら (1989)の研究で行われ た那覇市首里儀保と宮古島の蒸発散量を用いている(参考文献 7))。両地区 は亜熱帯性気候という気候条件および琉球石灰岩台地という地層構造が一 致しており、50\%とした

注 6) 蒸発散量については地表面の土地利用によって異なるものの、気候学 的もしくは水資源学的な見地からは、参考文献 8) 近藤 (1998)によって 「気候学的あるいは水資源的な観点からすると、ポテンシャル蒸発量は 地表面の種類によらず、地域の気候に固有な值であることが適当である」 と整理されており、既存研究でもそのように取り扱われている。そのため、 本研究では沖縄の既存調查、参考文献 7) 高里ら（1989）を参考に、沖縄 地方の気候に即した地域固有值として 0.5 を用いている。

注 7) 平成 18 年度宜野湾市自然環境調査 $\mathrm{p} 3-3$ では、各地表面の流出係数(1)宅 地·舗装道路 $0.95 \sim 0.70$ 、(2)草地・荒地 $0.17 \sim 0.13$ 、(3)森林地带 $0.40 \sim 0.20$ 、 (4)畑地・裸地 $0.30 \sim 0.10$ とある。本研究では土地利用用途別の各地表面の 流出係数は最大值と最小值の中間值を用いる。

注 8) E 流域は現在立ち入りが困難な米軍基地内 (キャンプ瑞慶覧内)に主要な湧 水が含まれており、独自の追加調査ができなかった。そのため、 $\mathrm{E}$ 流域の 水収支モデルの妥当性について検討ができないままである。

注 9）地下水・湧水の家庭用の利用として喜友名自治区及び伊佐自治区それぞれ 160 世帯、80 世帯、計 240 世帯の利用が確認されている。その内 38 世帯に使 用状況及び用途についてヒアリングを行った。

注 10）大山水田における水需要算定にあたり、専業及び兼業農家にヒアリン グを行った。その結果、土地の乾湿状況より、水の利用方法は大きく上流 部と下流部の 2 つに分類される。また、地下水の取水源 (メンダカリヒー ガー、アラナキガー、フルチンガー)および田芋の栽培方法 (A、B、C、D、E) に おいて水の利用方法がいくつかのケースに分類される。メン゙カリヒー ガーについては、個人で所有する水田で上流の水田で使用した湧水を下 流の水田でも使用していることが確認された。そこで上流と下流で同時 に使用している水田については一つの単位として計算した。ヒアリング で得られた典型的な栽培方法を模式図で表すと下記のようになっており、 植え付けからおおむね月単位で (v) 常時水を入れる、(w) 3 日に 1 回水を 入れる、 $(\mathrm{X})$ 週 1 回水を入れる、(Y) 天水のみ、(Z) 作業時のみと利用方法 を変化させて栽培している事がわかった。水田に引き込んでいる水路か らの取水口の時間あたり水量を容積法により計測し、単位時間の水量と 水田の水の入れ替え状況から水量を算出した(図補 3 )。

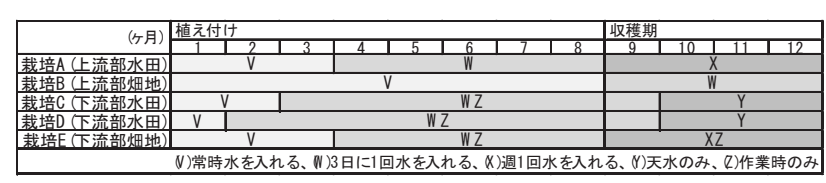

図補 3 田芋の育成過程と水の利用方法 
注 11) $\mathrm{A}$ 社 $\mathrm{B}$ 社 $\mathrm{C}$ 社の水需要量については、ヒアリングを行い使用状況及び用 途について確認した。各社とも地下水や湧水の取水状況はメーターで管理 しており、各月毎に 1 年分もしくは年間での利用量の回答であったが、汲 み上げた水の濾過装置の稼働状況や滤過を請け負う会社との契約状況の確 認から数值は真正であると判断した。また、地下水や湧水の取水は企業内 部で行われているが排水に関しては工業下水道を使っているため、宜野湾 市の下水道管理者にも内容を照会したところ、おおむ坟企業から回答され た数值が妥当である事が確認された。

注 12）喜友名自治区では、チュンナーガーより湧水を取水し、ポンプアップ により共同の水タンク（1958 年に設置）に貯水したのち、自然流下によ って各家庭への給水を行っている。水タンクの容量は、 2 万ガロン $(1$ ガ ロン $=3.785$ より 2 万ガロン $\left.=75.70 \mathrm{~m}^{3}\right)$ で 1 日 2 回ポンプアップによっ て貯水していることがヒアリングより得られた。また、ポンプアップ前 には、自治区低地部に立地する家庭で水が出にくい状況にあるとの証言 があったため、毎回くみ上げた量をほぼ使い切っているような状況であ ると判断できたため、下記の式で求めた。

$75.70 \mathrm{~m}^{3} \times 2$ 回/日 $\times 365$ 日 $=55,261 \mathrm{~m}^{3} /$ 年

以上より、喜友名自治区において、55,261 $\mathrm{m}^{3}$ 年使用していると推測し た。伊佐自治区では、喜友名自治区の約半数世帯であることから 27,630 $\mathrm{m}^{3}$ /年と推計した。両自治区での推計が合計で約 8.3 万 $\mathrm{m}^{3} /$ 年程度になる ため、家庭での利用量は多くても 10 万 $\mathrm{m}^{3}$ /年を超えない量と判断した。

注 13) C 流域の 123.1 万 $\mathrm{m}^{3} /$ 年は、個々の湧水の需要を満たす最低值である。 D 流域の 472.1 万 $\mathrm{m}^{3} /$ 年及び $\mathrm{E}$ 流域の 172.8 万 $\mathrm{m}^{3}$ 年については、現状並み の湧水量を確保することとした。

注 14）「中間とりまとめ」の中での緑地配置計画では、在来種である重要植生及 び地下水脈上、遺跡や文化財周辺の緑地については保全の方針が緑地の配 置と関連して示されており、これは計画的な合理性があるため同じ基地跡 地内の緑地でも再配置可能な緑地としては検討を行わなかった。広場的利 用を想定した緑地分について、流域毎の需要量から緑地の再配分が可能な ものとして扱った。

注 15）研究室提案では、D 流域より 28.3 万 $\mathrm{m}^{2}$ の緑地を C 及び $\mathrm{CD}$ 地下水流域 に再配分し、更に、C 及び $\mathrm{CD}$ 地下水流域の土地利用用途別流出係数の高 い振興ゾーン及び舗装・道路で 4.3 万 $\mathrm{m}^{2}$ 縮小して地下水涵養緑地 (芝地) として整備した。本研究で行った提案としては、 4.3 万 $\mathrm{m}^{2}$ 分の土地利用 用途の変更を行ったが、そのまま D 流域より 33 万 $\mathrm{m}^{2}$ の緑地の再配分 (総 量で見た用途の割合の変更を要しない再配分)を行っても、D 流域の水収 支には影響を与えない。

注 16）NBM は、ねたてのまちベースミーティングの略称で、普天間飛行場跡地計 画について市民が参加し考える会。 


\section{A PROPOSAL-BASED RESEARCH ABOUT THE OPEN SPACE PLANNING OF THE REUSE FUNDAMENTAL PLAN OF THE MARINE CORPS AIR STATION FUTENMA IN OKINAWA PREF., JAPAN}

- An action research for discussing the necessity of the watershed-based open space plan under the consideration of the water supply demand structure in Ginowan Area -

\section{Yuya ENOKAWA* and Hiroko ONO**}

\footnotetext{
* Under Graduate Student, Architecture Course, Faculty of Civil Engineering, University of Ryukyus ** Assoc. Prof., Faculty of Civil Engineering, University of Ryukyus, Ph.D.
}

After the Special Action Committee on Okinawa (SACO) agreement in 1996, Okinawa Prefecture and multiparty have been developing fundamental reuse plan with landowners and citizen. It was changed several times through expert investigations and discussions among them. 2013 plan has come to the halfway point of it. In the plan, some points, especially preservation policy of green, under ground water, and historical heritage in the base were reached consensus among parties. Despite some preservation policy of green and underground water, it has been missing throughout the water balance model study of this area. When people want to save the under ground water to reply the water demand, generally it needs an investigation of current water balance model and water use. So we started a proposal-based study about this research issues.

This study aimed to clarify two study objectives. The $1^{\text {st }}$ goal is to calculate exact a water balance model about approx. 1617ha of the 5 watershed areas, A,B,C,D and E, in Ginowan City where the Futenma Air Station is located in. At first, we calculate each land use ratio by GIS to simulate the amount of underground seepage of the rainfall in these 5 watershed areas. It is as for theoretical value. And the other hands, we also researched the amount of several water springs to calculate the amount of underground seepage of the rainfall in these areas as an observation value. The field surveys were held 60 times at each spring waters by flow speed measurement and positive displacement flowmeter. The observation value is in agreement with the theoretical value that we simulate. The finding and the fixed water balance model will contribute to the huge area planning like Futenma.

The $2^{\text {nd }}$ goal is to review the open space plan in Futenma reuse plan to fit water demands in these areas by using our water balance model. Because the today's 70\% of Futenma Air Station is covered green, it functions as like watershed protection forest. But according to contemporary Reuse plan, after the developing, the green area will decrease than today's area. According to our data gathered by interviewing to farmers and industrial officers who use under ground water and spring water, today's water demand reaches almost 5-62\% per supply from the natural condition. We analyzed the demand-supply water balance after the development, it will show over demand at some springs. And the worse more, there are some struggles between farmers in the dry season by the lack of water supply. This result is very important. Before our research, there is no report of the amount of water demand. It means that the demand-supply balance had not been paying little attention. Thus, we proposed to Prefecture Office and City Office to review the open space plan with considering water demands. We explained our analysis in detail at the closed meeting of them. Then almost of our concepts was accepted in the public plan.

This study's consequences and contribution are three points. 1) The water balance model of this area is established. 2) The under ground water and spring water demand of this area are calculated. 3) Through continuing discussion with parties, our proposal-based study is accepted in the public reuse plan of Futenma.

This work was supported by JSPS KAKENHI Grant Number JP24710168. 